\title{
25 Research Square \\ Heat Flow Data And Thermal Structure In North East Japan
}

\section{Takumi Matsumoto ( $\nabla$ mtakumi@bosai.go.jp )}

National Research Institute for Earth Science and Disaster Resilience https://orcid.org/0000-00021729-4602

\section{Ryuji Yamada}

National Research Institute for Earth Science and Disaster Resilience

Satoshi lizuka

National Research Institute for Earth Science and Disaster Resilience

\section{Research Article}

Keywords: Heat flow, Thermal structure

Posted Date: January 12th, 2022

DOI: https://doi.org/10.21203/rs.3.rs-1219862/v1

License: (c) (i) This work is licensed under a Creative Commons Attribution 4.0 International License. Read Full License 


\section{Abstract}

New heat flow data corrected for climate change over the entire northeastern region of Japan were obtained using the temperature profile of the borehole of NIED High Sensitivity Seismograph Network (Hinet). In addition, the crustal temperature structure was obtained by using a crustal structure model that takes into account the temperature dependence of thermal conductivity and the difference in heat generation due to lithology, using a crustal structure model that takes into account sedimentary layers rather than a uniform structure model with exposed bedrock at the surface. The results show that the crustal temperature structure in areas with thick sedimentary layers is improved compared to the previous model.

\section{Introduction}

Measurements of crustal heat flow and estimates of subsurface temperature structure based on these measurements are essential for determining the depth of the brittle/ductile transition in the crust, which is considered to be the lower limit of the seismogenic layer of the crust (Sibson,1984), understanding trench and slow earthquakes (e.g., Yoshioka et al., 2013), understanding the recent history of plate tectonic activity (Erkan and Blackwell, 2008, Tatsumi et al., 2020), and many other essential applications. In particular, a dense seismic observation network has been developed in Japan, and the detailed distribution of seismogenic layers has recently been revealed (Yano et al., 2017).

On the other hand, crustal heat flow data around the Japanese archipelago were first presented by Uyeda and Horai (1964), and many measurements were made in the terrestrial and oceanic regions (e.g., Yamano 1995). However, the terrestrial data were mainly measured from wells drilled in geothermal areas, and there are little data for non-geothermal areas. To compensate for this spatial distribution, we investigated the temperature profiles of 132 borehole wells (100-200 m deep) in Hi-net, a uniformly distributed seismic network over land in the Japanese archipelago. Thermal conductivity was measured from the deepest rock cores obtained during borehole drilling or estimated from the lithology when the measurement was difficult. From the results of processing the data, taking into account the effects of climate change and other factors, a new heat flow map was created to estimate the subsurface temperature structure.

\section{Tectonic Setting}

Northeastern Japan belongs to the Northeast Japan Arc, one of the typical island arc-trench systems formed by the subduction of cold plates in ancient times. Northeastern Japan is in contact with the Eurasian plate on the western side of the Sea of Japan. On the east side, the epicenter of 2011 off the Pacific coast of the Tohoku earthquake is located, and The Pacific Plate subducts westward at the Japan Trench under the Japanese islands. There are many volcanoes and earthquakes in the Tohoku region, and these active volcanoes and seismic zones are distributed almost parallel to the Japan Trench, the boundary of the plates. Active volcanoes are mainly distributed along the Ou spine, and the eastern edge 
of their distribution area forms the volcanic front. The distribution of volcanoes on the dorsal arc side extends to the Sea of Japan side in Northeastern Japan.

The back-arc opening of the Japan Sea began between 21 and $15 \mathrm{Ma}$, and normal faults developed in an extensional stress field until 13.5 Ma when volcanic belts also moved in the trench direction (Yoshida et al., 2013). After the opening of the Japan Sea at about $13.5 \mathrm{Ma}$, a period of neutral stress field continued (Yoshida et al., 2013). At about $4 \mathrm{Ma}$, the westward movement of the Pacific Plate increased (Pollitz 1986), followed by solid compression of the entire island arc. It is thought that most of the Miocene normal faults were reactivated, and the volcanic arc was uplifted (Yoshida et al., 2013). These imply tectonic inversion (Sato 1994) (see Figure 1).

\section{Data Collection}

\section{3-1. Hi-net borehole Temperature logging data}

After the disastrous 1995 Kobe earthquake, a new national project has drastically improved Japan's seismic observation system. Many strong-motion, high-sensitivity, and broadband seismographs were installed to construct dense and uniform networks covering the whole of Japan. (Okada et al., 2004). After The 2011 off the Pacific coast of Tohoku Earthquake, a submarine observation network was also constructed, and this integrated ocean-land observation network is called MOWLAS (Aoi et al., 2020). The high-sensitivity seismic observation network consisting of about 700 stations is called Hi-net.

Since the limit of the depth of the epicenter of inland earthquakes in Japan is usually $15-20 \mathrm{~km}$, it was necessary to construct a seismic observation network at intervals of $15-20 \mathrm{~km}$ in order to accurately determine the depth of the epicenter of earthquakes of such depth.

In order to perform stable and highly sensitive seismic observations by avoiding noise on the ground surface, seismometers are installed at the bottom of a borehole at a depth of more than $100 \mathrm{~m}$ at each $\mathrm{Hi}$-net station. Although most of the Hi-net stations have boreholes of 100-200 m in-depth, deep observation wells were made at specific sites if necessary.

Hi-net borehole wells are cased, and full-hole cemented around the casing for long-term stable observation (Okada et al., 2004). Therefore, there is no ingress or egress of groundwater, and good quality temperature profiles are expected to be obtained.

In the Tohoku region, Hi-net stations were constructed between 1998 and 2000. In addition, two stations were constructed in 2012 to replace those damaged by the Tohoku earthquake. Of the $133 \mathrm{Hi}$-net stations in the Tohoku region, 132 stations conducted thermal logging of each borehole well within a few months of the completion of drilling. For the observation wells with a depth of $100 \mathrm{~m}$ to $200 \mathrm{~m}$, the effect of thermal disturbance caused by mud circulation during drilling is considered to be small because the time required for drilling is short, and the temperature difference between the surface and the bottom of the well is slight, generally within $10^{\circ} \mathrm{C}$. In order to test this hypothesis, eight observation wells were re- 
examined after a certain period. However, it is not easy to conduct temperature logging in Hi-net boreholes with seismometers installed. Therefore, about six years after the drilling, the temperature logging was conducted by inserting an optical fiber into the borehole. The distributed temperature sensor (DTS) used was a Sumitomo Electric SUT-2. As a result, the difference between the temperature logging data obtained a few months after the end of drilling and the data obtained a few years later was small, and the temperature profiles obtained at both locations can now be considered to be of good quality with little influence from the temperature disturbance caused by drilling (see Figure 2).

\section{3-2. Thermal Conductivity}

Rock cores were taken at $30 \mathrm{~m}$ intervals in standard Hi-net boreholes and 250-500 m intervals in wells drilled to $1,000 \mathrm{~m}$ or more depths. Rock cores from about $70 \%$ of the observation wells were shaped, and thermal conductivity was measured using the QTM-500. The rock cores from the Hi-net boreholes, which account for about $60 \%$ of the total, were shaped, and the crustal heat flow rate was determined by measuring the thermal conductivity using the hot wire method with a QTM-500. For about $40 \%$ of the observation wells where thermal conductivity measurement by the hot wire method was difficult due to fracturing of the rock core, thermal conductivity was estimated by referring to the columnar map and PS logging results of the well. In the estimation, we referred to Sato et al (1999) and Gueguen and Palciauskas (1994).

In general, the thermal conductivity of surface soils in plain areas is said to be about $1.2 \mathrm{~W} / \mathrm{m} / \mathrm{K}$. However, according to the results of rock core tests in Hi-net boreholes in the Kanto region, the thermal conductivity is about 1.0-1.2 W/m/K even in Tertiary sedimentary layers near the elastic wave velocity decreases (Suzuki and Omura, 1999). Therefore, PS logging was also conducted in the Hi-net boreholes, and based on the logging results, the thermal conductivity of the surface soil in the plain area was set to 1.0 or $1.2 \mathrm{~W} / \mathrm{m} / \mathrm{K}$.

\section{Terrestrial Heat Flow}

\section{4-1. Data quality}

Borehole wells used for crustal heat flow analysis are often deeper than $300 \mathrm{~m}$ to avoid thermal disturbance caused by climate change, groundwater flow, and topographic effects. In the case of the Hinet borehole well, it is desirable to drill down to the basement rock to avoid surface ground noise. However, due to the spatial arrangement of the observation points, some wells are constructed in areas with thick sedimentary layers. Furthermore, as mentioned earlier, the Hi-net borehole wells are covered with a casing, and full-hole cementing prevents the inflow of water into the borehole, so very stable temperature gradient data is expected to be obtained.

In this study, the quality of the temperature logging data was evaluated by the characteristics of the T-D curve, referring to Erkan (2015), who performed heat flow analysis using shallow wells. The data were classified into four classes, A, B, C, D. Wells classified as Class A showed thermal conduction type 
temperature gradients over the entire depth, Class B showed thermal conduction type temperature gradients over $50 \%$ of the interval, Class $C$ showed groundwater influence over part of the interval, and Class D showed groundwater influence over the entire interval. The wells classified as Class D were determined to be unsuitable for heat flow analysis.

The rock cores were collected only in the deepest $25 \mathrm{~m}$ section. Therefore, the temperature gradient in the deepest $20 \mathrm{~m}$ section where the rock core was collected was used to analyze the crustal heat flow. The temperature gradients in the deepest $50 \mathrm{~m}$ or $200 \mathrm{~m}$ sections where the lithology remains the same were used to analyze the crustal heat flow for the two wells over $1000 \mathrm{~m}$.

\section{4-2. Climate change correction}

The subsurface temperature field is also known to record climatic changes at the surface. The effects of Pleistocene glaciation over several hundred thousand years extend several thousand meters below the surface, and climate change since the end of the 19th century has been particularly significant, affecting depths of 50 to 100 meters (Jessop 1990). Therefore, in determining the crustal heat flow rate, it is necessary to correct the effects of climate change for wells with depths between $100 \mathrm{~m}$ and $200 \mathrm{~m}$ in the $\mathrm{Hi}$-net standard specifications. Matsumoto (2007) calculated the crustal heat flow corrected for climate change, assuming a uniform temperature increase of $2^{\circ} \mathrm{C}$ over the past 100 years in the Japanese archipelago. However, it is said that there is a difference in the trend of temperature increase between suburban and non-urban areas, known as the heat island phenomenon, and this correction method was insufficient. Regarding climate change in Japan over the past 100 years, Fujibe (2012) quantitatively assessed the warming trend in the background (non-urban) and urban areas and found that the national average warming trend in the background (non-urban) daily mean temperature was $0.88^{\circ} \mathrm{C} / 100 \mathrm{yr}$, with the trend being stronger at stations with higher population density in the surrounding area (Table 2).

According to "Climate Change in the Tohoku Region" (Japan Meteorological Agency, 2016), the temperature in Sendai, the largest city in the Tohoku region, is $2.4^{\circ} \mathrm{C} / 100 \mathrm{yr}, 1.9^{\circ} \mathrm{C} / 100 \mathrm{yr}$ in Aomori, and $1.7^{\circ} \mathrm{C} / 100 \mathrm{yr}$ in Morioka. In the non-urban areas, many areas rely on the records of the past 50 years, with Fukaura at $0.4^{\circ} \mathrm{C} / 50 \mathrm{yr}$ and Miyako at $0.7^{\circ} \mathrm{C} / 100 \mathrm{yr}$. These results are in general agreement with those of Fujibe (2012).

Based on this model, we estimated the temperature increase over the past 100 years according to the population density around the boreholes, using the Regional Economic Analysis System (https://resas.go.jp/) operated by the Cabinet Office for data on population density as of 2005.

In this study, For the seven lithology models listed in Table.1, we evaluated the change in the geothermal gradient after 100 years of continuous increase in surface temperature, according to Jessop (1990). The parameters for the Quaternary sedimentary layers were taken from Miyakoshi et al. (2001). For the case where the lithology is granite, the initial temperature profile and the temperature profile 100 years after the surface temperature started to rise are shown. We also prepared three cases for the rate of temperature increase: $0.88^{\circ} \mathrm{C} / 100 \mathrm{yr}, 1.20^{\circ} \mathrm{C} / 100 \mathrm{yr}$, and $2.08^{\circ} \mathrm{C} / 100 \mathrm{yr}$ (Figure 3). The calculation results show that in 
Japan, the impact of climate change on the subsurface temperature gradient is very large up to a depth of $100 \mathrm{~m}$, and the degree of impact on the temperature gradient due to different rates of temperature increase is also very different.

There are three types of temperature profile data for Hi-net wells collected in this study. The first one is two wells deeper than $200 \mathrm{~m}$ depth that is less affected by the climate change in the recent 100 years described here. Therefore, these two borehole wells are not subject to correction for climate change. Next are the temperature data for standard wells with 100 to 200 meters depths. There are two sampling intervals for the temperature logging data here, one with a dense sampling interval of $1 \mathrm{~m}$ or $0.5 \mathrm{~m}$ and the other with a coarse sampling interval of $5 \mathrm{~m}$. For the former nine boreholes, we first tried fitting the observed T-D curve to the T-D curve calculated based on the temperature gradient of the initial conditions and the estimated temperature increase rate. The temperature gradient was arbitrarily assumed in units of $0.5^{\circ} \mathrm{C} / \mathrm{km}$, and the fitting temperature gradient was selected by visual inspection.

For the latter 121 wells ( 115 wells excluding the 6 Class D wells) that were coarsely sampled at $5 \mathrm{~m}$ intervals, a simple correction method was adopted because it was challenging to fit them using the same method as above.

Figure 4 shows the ratio of the temperature gradient after 100 years from the initial condition for five sections $(60-80 \mathrm{~m}, 80-100 \mathrm{~m}, 100-120 \mathrm{~m}, 130-150 \mathrm{~m}, 180-200 \mathrm{~m})$. The temperature rise rate shows three cases: $0.88^{\circ} \mathrm{C} / 100 \mathrm{yr}, 1.20^{\circ} \mathrm{C} / 100 \mathrm{yr}$, and $2.08^{\circ} \mathrm{C} / 100 \mathrm{yr}$, corresponding to non-urban areas, depopulated areas, and urban areas, respectively. For the lithology, two cases are shown, one with exposed basement rock and the other with sedimentary layers. The temperature gradient ratios before and after the 100-year lapse in Figure 3 were used as the climate change correction factors for the measured temperature profiles.

In the case of the most common $100 \mathrm{~m}$ borehole, the average temperature gradient of the $80-100 \mathrm{~m}$ section is used for comparison, but the corrected temperature gradient is generally $5-20 \%$ larger.

\section{4-3. Heat Flow Map}

Crustal heat fluxes at 127 stations were obtained by measuring temperature gradient values and thermal conductivities of rock cores. The crustal heat fluxes of 66 stations were obtained by measuring the thermal conductivity of rock cores, and 61 stations were obtained by using lithology estimates. Compared to Matsumoto (2007), the crustal heat flow rate is on average $4 \%$ larger in this study. On the other hand, the crustal heat flux estimated from the thermal conductivity as the average physical property of the Japanese archipelago is about $14 \%$ larger. In order to fill in the gaps in the distribution of Hi-net stations, the existing temperature logging data, Database on the Temperature Profiles of Boreholes in Japan (Sakagawa et al., 2004) (hereinafter referred to as DTPBJ), was examined for heat flow values, taking into account the geological conditions. 
However, because the DTPBJ includes many geothermal wells and hot spring wells in geothermal areas, many of these wells have been temperature logging immediately after drilling or not long enough after the temperature recovery test, and the temperature recovery is not sufficient. Therefore, we extracted only data from these vertically drilled borehole wells less affected by groundwater flow and showed good heat transfer type temperature profiles. The temperature gradient was determined when examining the heat flow rate by selecting the section where the temperature profile showed a straight line at the deep side. For high-temperature locations (above $100^{\circ} \mathrm{C}$ ), we attempted to correct the temperature dependence of thermal conductivity when using the thermal conductivity of core samples registered in DTPBJ.

Although most of the $5000 \mathrm{~m}$ class boreholes drilled for resource exploration were not drilled vertically, Akiyama and Hirai (1997) estimated the vertical temperature gradient in these boreholes, and this result was adopted in this study. In addition, the government MITI exploratory well Mishima, which is not included in the DTPBJ but was analyzed by Akiyama and Hirai (1997), was also analyzed in the same way as the DTPBJ. These results are shown in Taber.4.

Figure 5 is a map of heat flow in the earth's crust. We obtained heat flow data over a large area of the Tohoku region. It seems that there is a trend of less heat flow in the fore-arc and more heat flow in the volcanic regions, and some regions have slightly less heat flow in the back-arc. In the volcanic region of the Ou Mountains, the heat flow values are very different despite the close distance between the measurement points, suggesting that the influence of groundwater behavior is significant.

\section{Thermal Structure}

\section{5-1. Method}

Based on the crustal heat flow data obtained in this study, 1-D steady-state conductive geotherms are computed using finite difference approximations (e.g., Beardsmore and Cull, 2001). The 1-D heat conduction is shown in Equation (1), where $T$ is the temperature at depth $z, \lambda$ is the thermal conductivity,

and $\mathrm{A}$ is the crustal heat generation

$$
\text { generation. } \frac{\partial}{\partial z}\left(\lambda \frac{\partial T}{\partial z}\right)+A=0
$$

Therefore, we need to know the constituent materials of the subsurface, thermal conductivity, and crustal heat generation.

\section{5-2. Structure model}

This study follows Muto et al. (2013) and assumes a subsurface structure model for the Tohoku region. We consider the lithospheric structure obtained from wide-angle reflection and refraction seismic profiles throughout Tohoku, Japan. Following the petrological interpretation of the seismic structure of the Northeast Japan Arc by Nishimoto et al. (2005), we assume that the upper crust is granite, the lower crust is hornblende-bearing gabbro. The thickness of the upper crust is assumed to be $18 \mathrm{~km}$; according to 
Matsubara et al. (2017A), the depth of the Moho surface is distributed between $30 \mathrm{~km}$ and $35 \mathrm{~km}$, so we set the Moho surface at $30 \mathrm{~km}$ and calculate the temperature structure from the surface to $30 \mathrm{~km}$.

In the Tohoku region, there are plains with thick sedimentary layers and areas thickly covered with pyroclastic deposits. In order to estimate the subsurface temperature structure of these areas, it is necessary to incorporate the sedimentary layers into the subsurface structure model. For this purpose, the Shallow and deep layers combined model (SDLCM) (NIED, 2019) was used to obtain the depth of the basement rock at each observation point and improve the accuracy of the temperature structure estimation. Based on the information on the lithology of the borehole, four cases of crustal structure models were prepared (Figure. 6). In case 1, where the granite is exposed on the surface. In case 2, where the pre-tertiary basement rock is exposed, the basement rock is assumed to be the basement rock up to 5 $\mathrm{km}$, and the granite is assumed to be the basement rock from $5 \mathrm{~km}$ down. In case 3 , the thickness of the Tertiary sedimentary layer is used as the estimated depth of the basement rock at the well location, and the depth below is assumed to be granite. Finally, in case 4, where the bottom of the borehole is Quaternary sedimentary layers, the Quaternary sedimentary layers are assumed to be present up to a depth of $500 \mathrm{~m}$, the Tertiary sedimentary layers are assumed to be present from there to the estimated depth of the base rock, and the granite is assumed to be present below that.

\section{5-3. Thermal Conductivity}

The thermal conductivity of rocks tends to decrease with increasing temperature (e.g., Cermak and Rybach, 1982). Therefore, a model in which a simple linear function represents thermal conductivity and temperature is often used (Royer and Danis, 1988; Bodri et al., 1989). On the other hand, to take into account the large variability in the measured values, a model with a constant thermal conductivity in the upper crust is also used instead of a simple linear function model (Furukawa and Uyeda, 1986, Tanaka et al., 2009).

Miao et al. (2014) measured the thermal diffusivities and specific heat capacities of four types of rocks (granite, granodiorite, mafic rock, and hornblende) from room temperature to 1,173 K using the laser flash method and thermal analyzer simultaneously, and then combined them with density data to calculate the thermal conductivity. In this study, we use the results of Miao (2014) for granite and gabbro, which require calculations especially at high temperatures, and the equation of Funnel (1996) for other rocks and adopt a subsurface structure model with the temperature dependence of thermal conductivity.

\section{5-4. Heat generation}

Regarding the content of radioactive materials in rocks, which is necessary for estimating crustal heat generation, Minato (2005) conducted a detailed study on the concentration of $\mathrm{U}, \mathrm{K}$, and Th in soils in various parts of Japan. The difference between the data for soil and rock is not very large, and it is safe to assume that the relationship between $\mathrm{U}, \mathrm{K}$, and Th is reasonably well maintained even when soil is replaced by rock. Therefore, for rocks that make up the upper part of the earth's crust, such as sedimentary layers and igneous rocks, we used this as a reference, and for gabbroic rocks that make up 
the lower part of the earth's crust, we estimated radiogenic heating based on Beardsmore and Cull (2001).

Two models have been proposed for heat generation in the earth's crust: one that decreases with depth (e.g., Furukawa and Uyeda, 1986) and one that varies from layer to layer. (e.g., Erkan and Blackwell, 2008). This study adopts the layer model, defining multiple heating values depending on the crustal structure. Then, based on equation (2), the temperature $T$ can be expressed as follows.

$$
T=T s+\frac{Q}{\lambda} z-\frac{4}{2 \lambda} z^{2}
$$

Figure 7 shows examples of calculations for seven cases with heat flow rates ranging from $50 \mathrm{~mW} / \mathrm{m}^{2}$ to $200 \mathrm{~mW} / \mathrm{m}^{2}$ in $25 \mathrm{~mW} / \mathrm{m}^{2}$ increments. In the case of $75 \mathrm{~mW} / \mathrm{m}^{2}$, which is the average heat flow rate, the temperature reaches $300^{\circ} \mathrm{C}$ at a depth of about $11 \mathrm{~km}$, which seems reasonable compared to the depth of the seismogenic layer. In the case of $100 \mathrm{~mW} / \mathrm{m}^{2}$, the results are not much different from the calculation model of Okubo (1998). When the heat flow rate is large, the temperature dependence on the thermal conductivity becomes more pronounced, increasing the temperature. In the case of $50 \mathrm{~mW} / \mathrm{m}^{2}$, the attenuation effect of crustal heat flow due to radiogenic heating in the upper crust is significant. As a result, the temperature in the deep underground will be lower. However, as shown in Fig. 8, for example, when there is a thick sedimentary layer at the surface, the temperature gradient in the sedimentary layer increases and the heat generated in the earth's crust decreases, so the heat flow does not decrease with increasing depth, and the temperature deep underground tends to be higher.

\section{5-5. Solidus Temperature}

The partial melting state above the solidus temperature, where the assumption of one-dimensional heat conduction does not hold, is considered follows. In the upper crust, granitoid have solidus temperatures of $600-700^{\circ} \mathrm{C}$ at depths greater than $10 \mathrm{~km}$ (Robertson and Wyllie, 1971). The temperature of the lower crustal constituents, such as hornblende and waterless gabbro, is estimated to be $800-900^{\circ} \mathrm{C}$ (Tatsumi, 1994, Yoshida et al., 2005). Here, following the methods of Okubo et al. (1998) and Nishida and Hashimoto (2007), we assume that the temperature of the upper crustal solidus is $650^{\circ} \mathrm{C}$, the temperature of the lower crustal mafic rocks is $800^{\circ} \mathrm{C}$, and the temperature of the Moho surface ( $30 \mathrm{~km}$ depth) is $900^{\circ} \mathrm{C}$. In this region, the temperature increases monotonically with depth. Therefore, a simple model assumes that the temperature increases monotonically with depth in this region.

\section{5-6. Result}

The subsurface temperature was calculated for $126 \mathrm{Hi}$-net borehole wells, 86 DTPBJ wells, and $1 \mathrm{MITI}$ exploratory test well for 213 locations. Figure 9 shows the temperature distribution at depths of $5 \mathrm{~km}, 10$ $\mathrm{km}, 15 \mathrm{~km}$, and $20 \mathrm{~km}$, and Figure 10 shows the depth of the $300^{\circ} \mathrm{C}$ and $400^{\circ} \mathrm{C}$ isotherm. Depths are converted to depths from $0 \mathrm{~m}$ above sea level, not surface. The high heat flow region extends along the 
central axis of the Ou Mountains, and local high heat flow anomalies exist around volcanoes distributed along this axis. There are many places where the depth to $650^{\circ} \mathrm{C}$ is less than $5 \mathrm{~km}$ in these regions. On the other hand, in the coastal area on the forearc side where low heat flow regions of about $50 \mathrm{~mW} / \mathrm{m}^{2}$ exist, a low-temperature structure of about $300^{\circ} \mathrm{C}$ to $400^{\circ} \mathrm{C}$ is estimated at a depth of $30 \mathrm{~km}$. In the low heat flow region in the southern part of the back-arc, where the thickness of the sedimentary layer is as much as $5 \mathrm{~km}$, the temperature structure is about $300^{\circ} \mathrm{C}$ at a depth of $10 \mathrm{~km}$.

\section{Discussion}

\section{6-1. Heat Flow}

Compared with the previous study by Tanaka (2004), the spatial distribution of crustal heat flow characteristics shows almost the same trend. By interpolating the forearc side, where the amount of data was previously small, it can be said that the entire Tohoku region can now be covered, although the amount of data for the plains in the northern region is relatively small. In the Ou Mountains, where the present volcanic front is located, the heat flux is high, but on the fore-arc side, the heat flux is slightly higher than $\mathrm{VF}$, about $100 \mathrm{~mW} / \mathrm{m}^{2}$ in some areas.

The position of the VF in the Tohoku region was about 30-40 km east of its present position at $16 \mathrm{Ma}$, but it has moved from about $10 \mathrm{~km}$ west to east at $10 \mathrm{Ma}$ (Yoshida et al., 2013). It is conceivable that these past VF movements may still have left an impact on the thermal structure of the crust. Since $8 \mathrm{Ma}$, many large calderas have formed along the central axis of the Ou spine (Yoshida et al., 2013), but only one caldera has been identified on the forearc side of the present VF.

The time required to cool a magma reservoir with a diameter of $10 \mathrm{~km}$ is said to be about $1 \mathrm{Ma}$ (Tomiya, 2000), so the time scales may not match. On the other hand, there are cases where calderas are assumed to have been active for more than 600,000 years after their formation (Takehara et al., 2017), and hydrothermal reservoirs and low-velocity bodies have been observed beneath calderas formed in the Late Miocene (Sato et al., 2002). It has also been pointed out that magma reservoirs with lifetimes longer than several million years may exist if conditions like continuous fluid supply from deep underground are met (Yoshida et al. 2020). Therefore, it becomes important to compare the subsurface and temperature structures in high heat flow regions.

Temperature gradients associated with rising hydrothermal fluids can significantly impact regions around volcanoes.

Sakagawa et al. (2006) analyzed the crustal heat flux due to heat conduction and the heat flux due to fluid involvement in many borehole wells and estimated that as much heat as the heat conduction flux is transported to the surface by fluids.

Furthermore, Tamanyu (2008) proposed a model of hydrothermal convection related to the thickness of the sedimentary layers in each region and found that hydrothermal convection is dominant down to the 
depth of the Proterozoic basement rocks, from 1 to $3 \mathrm{~km}$ in plains and basins, and up to $1 \mathrm{~km}$ in volcanic regions. In such geothermal regions, hydrothermal convection systems are dominant. Therefore, in geothermal regions such as volcanic areas, the crustal heat flow rate may be overestimated when estimating the temperature structure at depths deeper than a few kilometers.

On the other hand, it has been pointed out that groundwater flow systems are widespread in the plains (Miyakoshi et al., 2001). In these areas, subsurface temperature gradients are complex, with large temperature gradients in the ascending groundwater basins and small temperature gradients in the descending basins (Uchida et al., 2014). For example, Kaneko et al. (2020) modeled the groundwater flow in the Sendai Plain; the Hi-net Sendai station is located in an area where the subsurface temperature is relatively high, and the temperature profile shows an upward flow type in the shallow part, which is consistent with this groundwater flow model.

On the other hand, most of the D-class wells, which were judged to have powerful groundwater influence, are located in the plains with thick sedimentary layers, and their temperature profiles show downward flow type. The temperature profiles of the Hi-net borings showed the influence of surface groundwater in about $10 \%$ of the stations, including the C-class wells that were judged to be partially affected.

Based on these results, more careful analysis considering the influence of groundwater may be necessary for borehole wells located in geological conditions where sedimentary layers are thick, and water can easily penetrate, especially in basins and plains.

\section{6-2 Thermal Structure}

In order to examine the validity of the calculated temperature structure, we first compare it with the D90 distribution of Omuralieva et al. (2012), which is an indicator of the lower limit of the seismogenic layer of the crust. There seems to be a good correlation between the temperature structure and the spatial distribution of $\mathrm{D} 90$, and the isotherm at a depth of $400^{\circ} \mathrm{C}$ is more correlated than the isotherm at $300^{\circ} \mathrm{C}$. The effect of introducing detailed crustal structure can be seen from the good correlation in the plains of the southern part of the Japan Sea, the epicenter of the 2004 Niigata-Chuetsu earthquake. However, compared to D90, the estimated temperature structure tends to be slightly higher, especially along the Ou Spine Mountains. On the other hand, there are also some areas where the temperature is estimated to be lower, mainly in the plains.

For a more accurate estimation, it may be useful to use an approach proposed by Sakagawa et al. (2004) to elaborately model the heat flux, which is the sum of heat conduction in the rock mass and heat transport by the fluid, as observed heat flow at the surface. In the future, it will be necessary to collaborate with groundwater models, for example, to separate the heat flux from the surface to 1 to $2 \mathrm{~km}$, where the influence of fluid is significant, from the heat conduction below the base rock conduction is dominant.

Next, we compare it with the Curie point temperature distribution by Ohkubo et al. (1989). This distribution, interpreted by Nishida and Hashimoto (2007) as corresponding to $400-450^{\circ} \mathrm{C}$, seems to have 
an excellent spatial correlation. Although both have resolution limitations, there seems to be a good correlation.

One way to verify the results of temperature calculations in deeper regions is to compare them with simulations of the temperature structure associated with plate subduction. Typically, it would be desirable to compare the estimated temperatures near the upper surface of the plate, but since the boundary of the subducted Pacific plate is deeper than $40 \mathrm{~km}$ in the Tohoku region, a simple comparison is difficult. On the other hand, when the temperature structure is compared with the hot finger model (Tamura et al., 2002), in which particularly hot areas of the mantle wedge are distributed at regular intervals, the spatial distribution of regions that are hotter than their surroundings appears to be in good agreement. Again, however, a quantitative comparison may be difficult in this study because the calculations are based on a simplified model above the Solidus temperature.

In this study, the crustal structure is assumed to be a simple horizontal layered structure with an upper crustal thickness of $18 \mathrm{~km}$ and a lower crustal thickness of $12 \mathrm{~km}$. In many models, the Moho surface is estimated to be deeper just below the Ou Mountains and slightly shallower on the frontal and back-arc sides (e.g., Nishimoto et al., 2005, Muto and Ohzono, 2012, Matsubara et al., 2017A), significantly since the thickness of the upper crust determines the total amount of crustal heat generation, and thus has a significant impact on the estimation of the temperature structure of the lower crust. Further discussion based on detailed structural models is needed; since the 3D seismic velocity structure shows a heterogeneous structure (e.g., Matsubara et al., 2017B), it is likely that the crustal constituents are not simply horizontally layered (e.g., Ishikawa et al., 2017). Since the thermal conductivity and the amount of radiative heat generation vary depending on the type of rock, it will be necessary to construct a 3-D structure that takes these characteristics into account.

Nakajima and Hasegawa (2003) proposed a model in which an S-wave reflection surface exists on the east side of the volcanic front and water is supplied from the lower crust. It will be necessary to study the effect of such fluid moving from the lower crust to the upper crust on the thermal structure.

In addition, the Tohoku region is an area where tectonic inversion is in progress (Sato 1994), and as Fukahata (2000) points out, the influence of the crust needs to be taken into account. If these issues can be overcome, it may be possible to improve the accuracy required for comparison with $\mathrm{D} 90$ and improve the accuracy of temperature estimation to the Moho surface.

\section{Conclusion}

New heat flow data covering the entire Tohoku region, corrected for climate change, was obtained using $\mathrm{Hi}$-net boreholes in the Tohoku region. The crustal thermal structure was also estimated based on the data. In order to estimate the crustal thermal structure, we used a crustal structure model that takes into account sedimentary layers, rather than a uniform subsurface structure model in which the bedrock is exposed to the ground surface and considered the temperature dependence of thermal conductivity and the difference in heat generation by lithology. This model is expected to improve the estimation of 
thermal structure in plains with thick sedimentary layers. It is hoped that this study will help develop an initial model for use in future complex analyses of crustal thermal structure.

\section{Declarations}

\section{Ethics approval and consent to participate}

Not applicable

\section{Consent for publication}

Not applicable

\section{Availability of data and materials}

The datasets used and/or analysed during the current study are available from the corresponding author on reasonable request.

\section{Competing interests}

The authors declare that they have no competing interests.

\section{Funding}

Not applicable.

\section{Authors' contributions}

TM conducted the data analysis and prepared the manuscript. RY Measured heat flow data and participated in the design of the discussion. SI participated in the design of the discussion. All of the authors read and approved the final manuscript

\section{Acknowledgements}

The authors are very grateful to Kenji Kasahara, Kazushige Obara, Katsuhiko Shiomi, Youichi Asano, Akiara Yamamoto and Kentaro Omura for their support of this work. Some of the figures were drawn using the Generic Mapping Tools software package (Wessel and Smith 1998).

\section{Authors' information}

TM, Principal Chief Researcher, National Research Institute for Earth Science and Disaster Resilience, 3-1 Tennodai, Tsukuba, Ibaraki 305-0006, Japan.

RY, Chief Researcher, National Research Institute for Earth Science and Disaster Resilience, 3-1 Tennodai, Tsukuba, Ibaraki 305-0006, Japan. 
SI, Principal Chief Researcher, National Research Institute for Earth Science and Disaster Resilience, 3-1 Tennodai, Tsukuba, Ibaraki 305-0006, Japan.

\section{References}

1. Aoi S, Asano Y, Kunugi T, Kimura T, Uehira K, Takahashi N, Ueda H, Shiomi K, Matsumoto T, Fujiwara H (2020) MOWLAS: NIED observation network for earthquake, tsunami and volcano. Earth Planets Space 72, 126. https://doi.org/10.1186/s40623-020-01250-x

2. Akiyama M, Hirai A (1997) Maximum paleotemperature gradient using vitrinite reflectance mainly of the government MITI exploratory test wells. Journal of the Japanese Association for Petroleum Technology, Vol.62, No.1 69-79. https://doi.org/10.3720/japt.62.69 (in Japanese with English abstract)

3. Beardsmore GR, Cull CP (2001) Crustal heat flow: a guide to measurement and modeling. Cambridge Univ. Press, Cambridge, UK.

4. Bodri B, lizuka S, Hayakawa M (1989) Modeling of deep temperature and heat flow in central Honshu, Japan. J. Geodynamics, 11, 105-129. https://doi.org/10.1016/0264-3707(89)90011-2

5. Cermak V, Rybach L (1982) Thermal properties, in Physical Properties of Rocks. edited by G. Angenheister, 305-481, Springer-Verlag, New York.

6. Erkan, K. Blackwell DD (2008) A thermal test of the post-subduction tectonic evolution along the California transform margin. Geophys. Res. Lett., 35, L07309. https://doi.org/10.1029/2008GL033479

7. Erkan K (2015) Geothermal investigations in western Anatolia using equilibrium temperatures from shallow boreholes. Solid Earth, 6, 103-113. https://doi.org/10.5194/se-6-103-2015

8. Fujibe $F$ (2012) Evaluation of background and urban warming trends based on centennial temperature data. Papers in Meteorology and Geophysics Vol. 63, 43-56. https://doi.org/10.2467/mripapers.63.43

9. Fukahata Y, Matsu'ura M (2000) Effects of active crustal movements on thermal structure in subduction zones. Geophys. J. Int. 141, 271-281. https://doi.org/10.1046/j.1365-246x.2000.00120.x

10. Funnell R, Chapman D, Allis R, Armstrong P (1996) Thermal state of the Taranaki Basin, New Zealand. J. Geophys. Res., 101, 25197-25215. https://doi.org/10.1029/96JB01341

11. Furukawa Y, Uyeda S (1986) Thermal State under Tohoku Arc with Consideration of Crustal Heat Generation. Volcanological Society of Japan, Vol.31, No.1,15-28. https://doi.org/10.18940/kazanc.31.1_15 (in Japanese with English abstract)

12. Gueguen Y, Palciauskas V (1994) Introduction to the physics of rocks. Princeton University Press.

13. Ishikawa M (2017) Deep crustal and uppermost mantle lithology of Island Arcs: Izu Arc and NE Honshu Arc. Jour. Geol. Soc. Japan, Vol. 123, No. 6, p. 355-364. https://doi.org/10.5575/geosoc.2017.0027 (in Japanese with English abstract) 
14. Ito Y, Tsuji T, Osada Y, Kido M, Inazu D, Hayashi Y, Tsushima H, Hino R, Fujimoto H (2011) Frontal wedge deformation near the source region of the 2011 Tohoku-Oki earthquake. Geophys. Res. Lett., 38, L00G05, https://doi.org/10.1029/2011GL048355

15. Iwasaki T, Kato W, Moriya T, Hasemi A, Umino N, Okada T, Miyashita K, Mizogami T, Takeda T, Sekine S, Matsushima T, Tashiro K. Miyamachi H (2001) Extensional structure in northern Honshu Arc as inferred from seismic refraction/wide-angle reflection profiling. Geophysical Research Letter, 28, 23292332. https://doi.org/10.1029/2000GL012783

16. Jessop AM. (1990), Thermal Geophysics. Elsevier, Amsterdam, 306p

17. JMA (2016) Climate Change in Tohoku. JMA, (in Japanese; available from https://www.data.jma.go.jp/sendai/knowledge/climate/change/report.html)

18. Kaneko S, Tomigashi A, Ishihara T, Shrestha G, Yoshioka M, Uchida Y (2020) Proposal for a Method Predicting Suitable Areas for Installation of Ground-Source Heat Pump Systems Based on Response Surface Methodology. Energies, 13(8), 1872. https://doi.org/10.3390/en13081872

19. Matsubara M, Sato H, Ishiyama T, Van Horne AD (2017A) Configuration of the Moho discontinuity beneath the Japanese Islands derived from three-dimensional seismic tomography. Tectonophysics, Vols.710-711, pp. 97-107. https://doi.org/10.1016/j.tecto.2016.11.025

20. Matsubara M, Sato H, Uehira K, Mochizuki M, Kanazawa T (2017B) Three-Dimensional Seismic Velocity Structure Beneath Japanese Islands and Surroundings Based on NIED Seismic Networks Using both Inland and Offshore Events. Journal of Disaster Research Vol.12 No.5. https://doi.org/10.20965/jdr.2017.p0844

21. Matsumoto $T$ (2007) Terrestrial heat flow distribution in Japan area based on the temperature logging in the borehole of NIED Hi-net. 2007 Fall Meeting, AGU, San Francisco, California, 10-14 Dec 2007. Abstract T23A-1217.

22. Miao SQ, Li HP, Chen G (2014) Temperature dependence of thermal diffusivity, specific heat capacity, and thermal conductivity for several types of rocks. J Therm Anal Calorim. 115, 1057-1063. https://doi.org/10.1007/s10973-013-3427-2

23. Minato S (2005) Uranium, Thorium and Potassium Concentrations in Japanese Soils. Radioisotopes, 54,509-515. https://doi.org/10.3769/radioisotopes.54.509

24. Miyakoshi A, Uchida Y (2001) Distribution of subsurface temperature and groundwater flow system in the Kanto Plain. Bull. Geol. Surv. Japan, Vol.52(6/7), p.253-290. https://doi.org/10.9795/bullgsj.52.253 (in Japanese with English abstract)

25. Muto J, Ohzono M (2012) Rheological profile across the northeastern Japan lithosphere toward precise modeling of the 2011 Tohoku Oki Earthquake. Jour. Geol. Soc. Japan, 118, 323-333. https://doi.org/10.5575/geosoc.2012.0026 (in Japanese with English abstract)

26. Muto J, Shibazaki B, Ito Y, linuma T, Ohzono, M, Matsumoto T, Okada T (2013) Two-dimensional viscosity structure of the northeastern Japan islands arc-trench system, Geophys. Res. Lett., 40, 4604-4608. https://doi.org/10.1002/grl.50906. 
27. National Research Institute for Earth Science and Disaster Resilience (2019) J-SHIS, National Research Institute for Earth Science and Disaster Resilience. https://doi.org/10.17598/nied.0012

28. Nakajima J, Hasegawa A (2003) Tomographic imaging of seismic velocity structure in and around the Onikobe volcanic area, northeastern Japan: implications for fluid distribution. J. Volcanol. Geotherm. Res., 127, 1-18, https://doi.org 10.101/S0377-0273(03)00155-0.

29. Nishida Y, Hashimoto T (2007) Geothermal structure of the crust and the upper mantle in Hokkaido, Japan: A review. Geophysical Bulletin of Hokkaido University, Sapporo, Japan. No.70, March 2007, pp.1-12. https://doi.org/10.14943/gbhu.70.1 (in Japanese with English abstract)

30. Nishimoto $S$, Ishikawa $M$, Arima $M$, Yoshida $T$ (2005) Laboratory measurement of $P$ wave velocity in crustal and upper mantle xenoliths from Ichino-megata, NE Japan: Ultrabasic hydrous lower crust beneath the NE Honshu arc. Tectonophysics, 396, 245-259.

https://doi.org/10.1016/j.tecto.2004.12.010

31. Nishisaka H, Shinohara M, Sato T, Hino R, Mochizuki K, Kasahara J (2001) Crustal structure of the Yamato basin and the margin of the north- eastern Japan Sea using ocean bottom seismographs and controlled sources. Zisin, 54(3), 365-379. https://doi.org/10.4294/zisin1948.54.3_365 (in Japanese with English abstract)

32. Okada Y, Kasahara K, Hori S, Obara K, Sekiguchi S, Fujiwara H, Yamamoto A (2004) Recent progress of seismic observation networks in Japan -Hi-net, F-net, K-NET and KiK-net. Earth Planets Space 56:15-28. https://doi.org/10.1186/BF03353076

33. Okubo Y, Tsu H, Ogawa K (1989) Estimation of Curie point temperature and geothermal structure of island arcs of Japan. Tectonophysics, 159, 279-290. https ://doi.org/10.1016/0040-1951(89)901340

34. Okubo Y, Akita F, Tanaka A (1998) Thermal Gradient Map and Thermal Structural Model -A Case Study of Hokkaido-. Journal of the Geothermal Research Society of Japan, Vol.20, No.1, p15-p29. https://doi.org/10.1016/0040-1951(89)90134-0

35. Omuralieva AM, Hasegawa A, Matsuzawa T, Nakajima J, Okada T (2012) Lateral variation of the cutoff depth of shallow earthquakes beneath the Japan Islands and its implications for seismogenesis. Tectonophysics, 518-521, 93-105. https://doi.org/10.1016/j.tecto.2011.11.013

36. Pollitz F (1986) Pliocene change in Pacific plate motion. Nature, 320, 738-741. https://doi.org/10.1038/320738a0

37. Robertson JK, Wyllie PJ (1971) Rock-water system, with special reference to the water-deficient region. Amer. J. Sci., 271, 252-277. https://doi.org/10.2475/ajs.271.3.252

38. Royer JJ, Danis M (1988) Steady state geothermal model of crust and the problem of the boundary conditions: application to a rift system, the southern Rhinegraben. Tectonophysics,156, 239-255. https://doi.org/10.1016/0040-1951(88)90062-5

39. Sakagawa Y, Umeda K, Suzuki M, Kajiwara T, Uchida Y (2004) Database on the Temperature Profiles of Boreholes in Japan. Zisin 57,63-67. https://doi.org/10.4294/zisin1948.57.1_63 (in Japanese) 
40. Sakagawa Y, Umeda K, Asamori K (2006) Heat Flux Distribution in Japan Taking Account of Advection Process. J. Geotherm. Res. Soc. Japan, vol.28, No.2, 211-221.

https://doi.org/10.11367/grsj1979.28.211

41. Sato H, Imaizumi T, Yoshida T, Ito H, Hasegawa A (2002) Tectonic evolution and deep to shallow geometry of Nagamachi-Rifu Active Fault System, NE Japan. Earth, Planets and Space, 54, 10391043. https://doi.org/10.1186/BF03353298

42. Sato T, Taniguchi W, Fujita T, Hasegawa H (1999) Data Collection by Literature Survey on Rock Physical Properties in Japan (II), JNC TN7400 99-011, Japan Nuclear Cycle Development Institute (in Japanese with English abstract). https://jopss.jaea.go.jp/pdfdata/JNC-TN7400-99-011.pdf. Accessed 2 Oct 2021

43. Sibson, R.H. (1984) Roughness at the base of the seismogenic zone: Contribution factors. J. Geophys. Res., Vol. 89, pp. 5791-5799. https://doi.org/10.1029/JB089iB07p05791

44. Suzuki H, Omura K (1999) Geological and Logging Data of the Deep Observation Wells in the Kanto Region. Japan, Technical Note of the National Research Institute for Earth Science and Disaster Resilience, No. 191. https://doi.org/10.24732/nied.00001805 (in Japanese with English abstract)

45. Takahashi N, Kodaira S, Tsuru T, Park J.-O, Kaneda Y, Suyehiro K, Kinoshita H, Abe S, Nishio M, Hino R (2004) Seismic structure and seismogenesis off Sanriku region, northeastern Japan. Geophys. J. Int., 159, 129-145. https://doi.org/ 10.1111/j.1365-246X.2004.02350.x

46. Takehara M, Horie K, Tani K, Yoshida T, Hokada T, Kiyokawa S (2017) Timescale of magma chamber processes revealed by U-Pb ages, trace element contents and morphology of zircons from the Ishizuchi caldera, Southwest Japan Arc. Island Arc, 26, e12182. https://doi.org/10.1111/iar.12182.

47. Tamanyu S (2008) Classification of wide areas including high-temperature regions from the viewpoint of subsurface temperature distribution -Examples of Tohoku and Chugoku/Shikoku districts. Bull. Geol. Surv. Japan, vol. 59(1/2), p.45 - 52. https://doi.org/10.9795/bullgsj.59.45 (in Japanese with English abstract)

48. Tamura Y, Tatsumi Y, Zhao D, Kido Y, and Shukuno H (2002) Hot fingers in the mantle wedge: New insights into magma genesis in subduction zones. Earth Planet. Sci. Lett., 197, 105-116. https://doi.org/10.1016/S0012-821X(02)00465-X

49. Tanaka A, Yamano M, Yano Y, Sasada M (2004), Geothermal gradient and heat flow data in and around Japan (I): Appraisal of heat flow from geothermal gradient data. Earth Planets Space, 56, 1191-1194. https://doi.org/10.1186/BF03353339

50. Tanaka A (2009) Lithospheric thermal structure: one of factors influencing depth of earthquakes. Zisin 61(Supplement): S239-S245. https://doi.org/10.4294/zisin.61.239 (in Japanese with English abstract)

51. Tatsumi Y, Furukawa Y, Yamashita S (1994) Thermal and geochemical evolution of the mantle wedge in the northeast Japan arc 1. Contribution from experimental petrology. Journal of Geophysical Research, 99, 22 275-22 283. https://doi.org/10.1029/94JB00283 
52. Tatsumi Y, Suenaga N, Yoshioka S, Kaneko K, Matsumoto T (2020) Contrasting volcano spacing along SW Japan arc caused by difference in age of subducting lithosphere. Scientific Reports volume 10, Article number: 15005. https:// doi.org/10.1038/s41598-020-72173-6

53. Tomiya A (2000) Influence of a Magma Chamber on Thermal Structure of the Surrounding Crust. Bulletin of the Volcanological Society of Japan, Vol.45, Issue 3, 173-179. https://doi.org/10.18940/kazan.45.3_173 (in Japanese with English abstract)

54. Uchida Y, Yoshioka M, Shrestha G (2014) Evaluation of potential for ground-source heat pump system based on hydrogical data, Butsuri-Tansa. Vol. 67, No. 1, 25-36. https://doi.org/10.3124/segj.67.25 (in Japanese with English abstract)

55. Uyeda S, Horai K (1964) Terrestrial heat flow in Japan. J. Geophys. Res.,69, 2121-2141. https://doi.org/10.1029/JZ069i010p02121

56. Wessel P, Smith WHF (1998) New, improved version of Generic Mapping Tools released. EOS Trans Am Geophys Un 79:579.

57. Yamano M (1995) Recent heat flow studies in and around Japan, in Terrestrial Heat Flow and Geothermal Energy in Asia. edited by M. L. Gupta and M. Yamano, pp.173-201, A. A. Balkema, Rotterda.

58. Yano ET, Takeda T, Matsubara M, Shiomi K (2017) Japan unified high-resolution relocated catalog for earthquakes (JUICE): Crustal seismicity beneath the Japanese Islands. Tectonophysics, 702, 1928. https://doi.org/10.1016/j.tecto.2017.02.017

59. Yoshida T, Nakajima J, Hasegawa A, Sato H, Nagahashi Y, Kimura J, Tanaka A, Prima ODA, Ohguchi T (2005) Evolution of late Cenozoic magmatism in the NE Honshu Arc and its relation to the crustmantle structure. Quaternary Research, 44, 195-216. https://doi.org/10.4116/jaqua.44.195 (in Japanese with English abstract)

60. Yoshida T, Kimura J, Yamada R, Acocella V, Sato H, Zhao D, Nakajima J, Hasegawa A, Okada T, Honda S, Ishikawa M, Prima ODA, Kudo T, Shibazaki B, Tanaka A Imaizumi T (2013) Evolution of late Cenozoic magmatism and the crust-mantle structure in the NE Japan Arc. Geological Society, London, Special Publications, 385, 335-387, 24 September. https://doi.org/10.1144/SP385.15

61. Yoshida T, Takashima R, Kudo T, Prima ODA, Maeda S, Yoshida K, Okada T, Miura S, Takahashi T, Nagahashi Y, Kataoka K (2020) Late Cenozoic Igneous Activity and Crustal Structure in the NE Japan Arc: Background of Inland Earthquake Activity. Journal of Geography, 129(4), 529563. https://doi.org/10.5026/jgeography.129.529(in Japanese with English abstract)

62. Yoshioka S, Suminokura Y, Matsumoto T, Nakajima J (2013) Two-dimensional thermal modeling of subduction of the Philippine Sea plate beneath southwest Japan. Tectonophysics 608, 1094-1108. https://doi.org/10.1016/j.tecto.2013.07.003

\section{Tables}

Due to technical limitations, tables 1-5 are only available as a download in the Supplemental Files section. 


\section{Figures}

\section{Figure 1}

Tectonic setting of the Northeastern part of Japan.

Tectonic setting of the Northeastern part of Japan. Quaternary volcanoes in the Tohoku region arc are shown by red triangles. Active volcanoes are also shown by pink triangles. The thick black cross indicates a Hi-net observation sites.

\section{Figure 2}

2-1囚2-5 Temperature profiles of Hi-net boreholes.

Temperature profiles of Hi-net boreholes. The red dots show the data from the first temperature logging and the blue dots show the data from the second temperature logging.

\section{Figure 3}

The temperature profile changes with climate change.

The temperature profile changes with climate change. The lithology is granite. The temperature gradient is $10^{\circ} \mathrm{C} / \mathrm{km}, 20^{\circ} \mathrm{C} / \mathrm{km}, 30^{\circ} \mathrm{C} / \mathrm{km}, 40^{\circ} \mathrm{C} / \mathrm{km}, 50^{\circ} \mathrm{C} / \mathrm{km}, 60^{\circ} \mathrm{C} / \mathrm{km}, 80^{\circ} \mathrm{C} / \mathrm{km}$, and $100^{\circ} \mathrm{C} / \mathrm{km}$ in eight cases. (1) shows the initial condition, (2), (3), and (4) show the conditions after 100 years. The background colors of the $60-80 \mathrm{~m}, 80-100 \mathrm{~m}, 100-120 \mathrm{~m}, 130-150 \mathrm{~m}$, and $180-200 \mathrm{~m}$ sections are associated with the graphs in Figure 4.

\section{Figure 4}

Assessing the impact of climate change on temperature gradients at different depths. The temperature gradient ratios after 100 years from the initial state are shown for five depth sections $(60-80 \mathrm{~m}, 80-100 \mathrm{~m}$, 100-120 m, 130-150 m, and 180-200 m). The ratios of temperature gradient after 100 years from the initial state are shown. Three cases of temperature increase rates are shown: $0.88^{\circ} \mathrm{C}$ for $(1-a)$ and $(1-b)$, $1.2^{\circ} \mathrm{C}$ for (2-a) and (2-b), and $2.0^{\circ} \mathrm{C}$ for (3-a) and (3-b), which correspond to non-urban areas, depopulated 
areas, and urban areas, respectively. As for the lithology, the cases of exposed basement rock ((1-a), (2-a), (3-a)) and sedimentary layers ((1-b), (2-b), (3-b)) are shown. The colors of the lines in the graphs correspond to those in Figure 3. If the observed temperature gradient is Gobs, the corrected temperature gradient is $G c o r$, the temperature gradient 100 years ago is $G(T=0)$, and the current estimated temperature gradient is $G(T=100)$, then $G$ cor $=G o b s \times G(T=0) / G(T=100)$, and the inverse of the $y$-axis in this figure can be multiplied by the observed temperature gradient to obtain the corrected temperature gradient.

\section{Figure 5}

Distribution of terrestrial heat flow.

The circles indicate the heat flow at the Hi-net station, and the squares indicate the heat flow at the DTPBJ (Sakagawa et al., 2004).

\section{Figure 6}

Crustal structure models. The upper crust is granite, and the lower crust is gabbro. The thickness of the upper crust is $18 \mathrm{~km}$, and the depth of the Moho surface is $30 \mathrm{~km}$. Four cases were assumed in the model, depending on the type of rock exposed at the surface and the thickness of the sedimentary layers.

\section{Figure 7}

Example of underground temperature calculation (1)

The examples of calculations for seven cases with heat flow rates ranging from $50 \mathrm{~mW} / \mathrm{m}^{2}$ to 200 $\mathrm{mW} / \mathrm{m}^{2}$ in $25 \mathrm{~mW} / \mathrm{m}^{2}$ increments.

\section{Figure 8}

Example of underground temperature calculation (2)

An example calculation showing the effect of a sedimentary layer. The crustal heat flow rate is 50 $\mathrm{mW} / \mathrm{m}^{2}$. The crustal structure corresponds to Case 3 on Figure 7. 


\section{Figure 9}

Estimated subsurface temperature map.

The crustal temperature structure depths of $5 \mathrm{~km}, 10 \mathrm{~km}, 15 \mathrm{~km}$, and $20 \mathrm{~km}$.

\section{Figure 10}

The depth of the $300^{\circ} \mathrm{C}$ and $400^{\circ} \mathrm{C}$ isotherm.

\section{Supplementary Files}

This is a list of supplementary files associated with this preprint. Click to download.

- TableFiles01.xlsx

- Cover.png 